\title{
Effects of tillage, rotation and cover crop on the physical properties of a silt-loam soil**
}

\author{
Samuel Idoko Haruna ${ }^{1,2}$ and Nsalambi Vakanda Nkongolo ${ }^{1,3 *}$ \\ ${ }^{1}$ Department of Agriculture and Environmental Sciences, Lincoln University, 307 Founders Hall, Jefferson City, \\ MO 65102-0029, USA \\ ${ }^{2}$ Department of Soil, Environmental and Atmospheric Sciences, University of Missouri, Natural Resources Building, \\ 302 Anheuser-Busch, Columbia, MO 65211-0001, USA \\ ${ }^{3}$ Faculty Institute of Agricultural Sciences (IFA), Yangambi, B.P. 1232, Kisangani, Democratic Republic of Congo \\ Received January 13, 2015; accepted April 20, 2015
}

\begin{abstract}
A b s t r a c t. Soil and crop management practices can affect the physical properties and have a direct impact on soil sustainability and crop performance. The objective of this study was to investigate how soil physical properties were affected by three years of tillage, cover crop and crop rotation treatments in a corn and soybean field. The study was conducted on a Waldron siltyloam soil at Lincoln University of Missouri. Soil physical properties studied were soil bulk density, volumetric and gravimetric water contents, volumetric air content, total pore space, air-filled and water-filled pore space, gas diffusion coefficient and pore tortuosity factor. Results showed significant interactions $(p<0.05)$ between cover crop and crop rotation for bulk density, gravimetric and total pore space in 2013. In addition, cover crop also significantly interacted $(\mathrm{p}<0.05)$ with tillage for bulk density and total pore space. All soil physical properties studied were significantly affected by the depth of sampling $(\mathrm{p}<0.0001)$, except for bulk density, the pore tortuosity factor and total pore space in 2012, and gravimetric and volumetric in 2013. Overall, soil physical properties were significantly affected by the treatments, with the effects changing from one year to another. Addition of a cover crop improved soil physical properties better in rotation than in monoculture.
\end{abstract}

$\mathrm{K}$ e y w o r d s: cover crop, rotation, tillage, soil physical properties, corn/soybean

\section{INTRODUCTION}

Soil and crop management practices have the potential to provide several benefits to farmers and to the ecosystem, and have been studied by many authors (Blanco-Canqui et al., 2011; Hill, 1990; Osunbitan et al., 2005; Özgöz et al., 2007; Radcliffe et al., 1988; Raper et al., 2000; Sharratt

*Corresponding author e-mail: nkongolo@lincolnu.edu

**This work is part of a regional collaborative project supported by the USDA-NIFA, Award No. 2011-68002-30190, 'Cropping Systems Coordinated Agricultural Project: Climate Change, Mitigation, and Adaptation in Corn-based Cropping Systems'. Project Web site: http://sustainablecorn.org et al., 2006). However, studies on these soil management practices, especially tillage, have yielded conflicting results for soil properties in general and for soil physical properties in particular. For soil bulk density, as an example, after 14 years of tillage practice, Anken et al. (2004) found that tillage did not significantly affect soil bulk density. Similar results were also reported by Arshad et al. (1999), Logsdon et al. (1999) and Taboada et al. (1998) in much shorter studies.

In contrast, Hill (1990) and Mahboubi et al. (1993) found greater soil bulk density in no-tillage compared with conventional tillage. Other studies also reported that soil bulk density was greater in no-till in the $5-10 \mathrm{~cm}$ soil depth as compared to tillage (Grant and Lafond, 1993; Osunbitan et al., 2005; Radcliffe et al., 1988; Rhoton et al., 1993; Strudley et al., 2008; Wander and Bollero, 1999; Hussain et al., 1998).

Besides soil bulk density, other soil properties were also differently affected by soil tillage. Hussain et al. (1998) noted higher water content within a no-tillage system than within conventional tillage. In a 20-year study, Sharratt et al. (2006) reported that no-tillage had greater soil penetration resistance and water content compared to all other tillage treatments. Similar results were also reported by Hill (1990) and Mahboubi et al. (1993). Some authors have finally suggested that tillage practices can also alter soil physical properties and, consequently, the surface and subsurface hydrology of agricultural fields, especially when a similar tillage system has been practiced for a long period (Buschiazzo et al., 1998; Gómez et al., 1999; Hill, 1990; Özgöz et al., 2007; Tsegaye and Hill, 1998).

(C) 2015 Institute of Agrophysics, Polish Academy of Sciences 
The discrepancies in the results previously reported on the effects of soil and crop management practices on soil physical properties suggest that more studies needs to be conducted. Furthermore, in many of these previous studies, the effect of one or two management practices such as tillage or cover crop or rotation on soil properties was studied. Few studies have looked at a combination of several of these soil and crop management practices on soil physical properties. The objective of this study was therefore to investigate the effects of a combination of tillage, crop rotation and cover crop on soil physical properties.

\section{MATERIALS AND METHODS}

The study was conducted at Lincoln University of Missouri Freeman farm in Jefferson City from 2011 to 2013. The site is located between latitude $38^{\circ} 58^{\prime} 16^{\prime \prime} \mathrm{N}$ and longitude $92^{\circ} 10^{\prime} 53^{\prime \prime} \mathrm{W}$, in the bottom land of the Missouri river. The elevation is $166 \mathrm{~m}$ above sea level with a $2 \%$ slope (Fig. 1). The soil type is a Waldron silt loam (Fine, smectitic, calcareous, mesic Aeric Fluvaquents). It has a fine sub-angular blocky structure in the Ap horizon which extends from the surface to a depth of about $20 \mathrm{~cm}$. The Ap horizon is underlain by $\mathrm{C} 1(20-35 \mathrm{~cm}), \mathrm{C} 2$ $(35-43 \mathrm{~cm}), \mathrm{Cg} 1(43-71 \mathrm{~cm}), \mathrm{Cg} 2(71-101 \mathrm{~cm})$ and $\mathrm{Cg} 3$ $(101-152 \mathrm{~cm})$ horizons, all of similar structure. The mean annual precipitation between 2011 and 2013 was $990.6 \mathrm{~mm}$, with the months of May and January usually receiving the highest $(127 \mathrm{~mm})$ and lowest $(50.8 \mathrm{~mm})$ precipitations, respectively. However, 2012 was a particularly dry year with an average precipitation of about $752.09 \mathrm{~mm}$. Twenty four plots of each corn (Zea mays) and soybean (Glycine max) were established on a 4.05 ha field and arranged in a 3 -factor factorial design with 3 replications. Each of the plots had a length and breadth of $12.2 \times 21.3 \mathrm{~m}$. The 3 factors (treatments) were tillage at two levels (no-tillage $v s$. conventional [mouldboard plough] tillage), cover crop at two levels (no-rye vs. rye) and rotation at four levels (continuous corn, continuous soybean, corn/soybean and soybean/corn rotations). The field was mouldboard ploughed (henceforth referred to as conventional tillage) before planting corn and soybean. Corn and soybean were planted each year in late May/early June and harvested in late October. Rye (Secale cereale) was planted in 12 plots of each corn and soybean immediately after corn and soybean harvest. All corn and soybean plots received $26 \mathrm{~kg} \mathrm{~N}, 67 \mathrm{~kg}$ $\mathrm{P}_{2} \mathrm{O}_{5}$, and $67 \mathrm{~kg} \mathrm{~K}_{2} \mathrm{O} \mathrm{ha}{ }^{-1}$. However, the corn plots received an additional $202 \mathrm{~kg} \mathrm{~N} \mathrm{ha}^{-1}$ from urea.

Soil samples were taken two weeks after tillage and planting in 2011 and at the end of the growing seasons in 2012 and 2013 (after rye harvest). They were taken at points in the centre of each plot with no trafficking to avoid compaction. They were taken using cylindrical cores with a diameter of $6.3 \mathrm{~cm}$ at four different depths of $0-10,10-20$, 20-40, and 40-60 cm, corresponding to depths 1,2,3 and 4, respectively. Because of the difference in sampling depths, the cylindrical cores used were of two different heights: 10 and $20 \mathrm{~cm}$ for samples at: $0-10,10-20 \mathrm{~cm}$ and $20-40$, $40-60 \mathrm{~cm}$, respectively. The volumes $(\mathrm{V})$ of the cores were 311.57 and $622.98 \mathrm{~cm}^{3}$ for 10 and $20 \mathrm{~cm}$ probe, respectively. The soil samples were then taken to Lincoln University Dickenson research laboratory where they were weighed (wet weight of sample, WWS), then oven dried at $105^{\circ} \mathrm{C}$

\begin{tabular}{|c|c|c|c|c|c|c|c|c|c|c|c|}
\hline $\begin{array}{c}1 . \\
\text { Con Corn } \\
\text { No Rye } \\
\text { No Till }\end{array}$ & $\begin{array}{c}\mathbf{2 .} \\
\text { SB/C } \\
\text { No Rye } \\
\text { No Till }\end{array}$ & $\begin{array}{c}3 . \\
\text { Con SB } \\
\text { No Rye } \\
\text { No Till }\end{array}$ & $\begin{array}{c}\mathbf{4 .} \\
\text { C/SB } \\
\text { No Rye } \\
\text { No Till }\end{array}$ & $\begin{array}{c}\mathbf{5 .} \\
\text { Con SB } \\
\text { Rye } \\
\text { Conv. Till }\end{array}$ & $\begin{array}{c}\mathbf{6 .} \\
\text { C/SB } \\
\text { Rye } \\
\text { Conv. Till }\end{array}$ & $\begin{array}{c}7 . \\
\text { SB/C } \\
\text { Rye } \\
\text { Conv. Till }\end{array}$ & $\begin{array}{c}\mathbf{8 .} \\
\text { Con Corn } \\
\text { Rye } \\
\text { Conv. Till }\end{array}$ & $\begin{array}{c}9 . \\
\text { C/SB } \\
\text { Rye } \\
\text { No Till }\end{array}$ & $\begin{array}{c}\mathbf{1 0 .} \\
\text { SB/C } \\
\text { Rye } \\
\text { No Till }\end{array}$ & $\begin{array}{c}11 . \\
\text { Con SB } \\
\text { Rye } \\
\text { No Till }\end{array}$ & $\begin{array}{c}12 . \\
\text { Con Corn } \\
\text { Rye } \\
\text { No Till } \\
\end{array}$ \\
\hline $\begin{array}{c}\mathbf{2 4 .} \\
\text { C/SB } \\
\text { Rye } \\
\text { No Till }\end{array}$ & $\begin{array}{c}23 . \\
\text { Con SB } \\
\text { Rye } \\
\text { No Till } \\
\end{array}$ & $\begin{array}{c}22 . \\
\text { SB/C } \\
\text { Rye } \\
\text { No Till }\end{array}$ & $\begin{array}{c}21 . \\
\text { Con Corn } \\
\text { Rye } \\
\text { No Till } \\
\end{array}$ & $\begin{array}{c}\mathbf{2 0 .} \\
\text { Con SB } \\
\text { No Rye } \\
\text { Conv. Till }\end{array}$ & $\begin{array}{c}19 . \\
\text { Con Corn } \\
\text { No Rye } \\
\text { Conv. Till }\end{array}$ & $\begin{array}{c}18 . \\
\text { SB/C } \\
\text { No Rye } \\
\text { Conv. Till }\end{array}$ & $\begin{array}{c}17 . \\
\text { C/SB } \\
\text { No Rye } \\
\text { Conv. Till }\end{array}$ & $\begin{array}{c}16 . \\
\text { C/SB } \\
\text { No Rye } \\
\text { No Till } \\
\end{array}$ & $\begin{array}{c}15 . \\
\text { Con SB } \\
\text { No Rye } \\
\text { No Till } \\
\end{array}$ & $\begin{array}{c}14 . \\
\text { Con Corn } \\
\text { No Rye } \\
\text { No Till }\end{array}$ & $\begin{array}{c}13 . \\
\text { SB/C } \\
\text { No Rye } \\
\text { No Till }\end{array}$ \\
\hline $\begin{array}{c}\mathbf{2 5 .} \\
\text { Con SB } \\
\text { No Rye } \\
\text { Conv. Till } \\
\end{array}$ & $\begin{array}{c}\mathbf{2 6 .} \\
\text { Con Corn } \\
\text { No Rye } \\
\text { Conv. Till } \\
\end{array}$ & $\begin{array}{c}27 . \\
\text { SB/C } \\
\text { No Rye } \\
\text { Conv. Till } \\
\end{array}$ & $\begin{array}{c}\mathbf{2 8 .} \\
\text { C/SB } \\
\text { No Rye } \\
\text { Conv. Till }\end{array}$ & $\begin{array}{c}29 . \\
\text { Con Corn } \\
\text { No Rye } \\
\text { No Till }\end{array}$ & $\begin{array}{c}\text { 30. } \\
\text { Con SB } \\
\text { No Rye } \\
\text { No Till } \\
\end{array}$ & $\begin{array}{c}\text { 31. } \\
\text { C/SB } \\
\text { No Rye } \\
\text { No Till } \\
\end{array}$ & $\begin{array}{c}\text { 32. } \\
\text { SB/C } \\
\text { No Rye } \\
\text { No Till } \\
\end{array}$ & $\begin{array}{c}33 . \\
\text { Con SB } \\
\text { No Rye } \\
\text { Conv. Till }\end{array}$ & $\begin{array}{c}\text { 34. } \\
\text { C/SB } \\
\text { No Rye } \\
\text { Conv. Till }\end{array}$ & $\begin{array}{c}35 . \\
\text { Con Corn } \\
\text { No Rye } \\
\text { Conv. Till }\end{array}$ & $\begin{array}{c}36 . \\
\text { SB/C } \\
\text { No Rye } \\
\text { Conv. Till }\end{array}$ \\
\hline $\begin{array}{c}48 . \\
\text { SB/C } \\
\text { Rye } \\
\text { Conv. Till }\end{array}$ & $\begin{array}{c}47 . \\
\text { C/SB } \\
\text { Rye } \\
\text { Conv. Till } \\
\end{array}$ & $\begin{array}{c}46 . \\
\text { Con Corn } \\
\text { Rye } \\
\text { Conv. Till } \\
\end{array}$ & $\begin{array}{c}\mathbf{4 5 .} \\
\text { Con SB } \\
\text { Rye } \\
\text { Conv. Till } \\
\end{array}$ & $\begin{array}{c}44 . \\
\text { SB/C } \\
\text { Rye } \\
\text { No Till }\end{array}$ & $\begin{array}{c}\mathbf{4 3} . \\
\text { Con SB } \\
\text { Rye } \\
\text { No Till } \\
\end{array}$ & $\begin{array}{c}\mathbf{4 2 .} \\
\text { Con Corn } \\
\text { Rye } \\
\text { No Till } \\
\end{array}$ & $\begin{array}{c}41 . \\
\text { C/SB } \\
\text { Rye } \\
\text { No Till }\end{array}$ & $\begin{array}{c}\mathbf{4 0 .} \\
\text { Con Corn } \\
\text { Rye } \\
\text { Conv. Till }\end{array}$ & $\begin{array}{c}39 . \\
\text { SB/C } \\
\text { Rye } \\
\text { Conv. Till }\end{array}$ & $\begin{array}{c}\text { 38. } \\
\text { C/SB } \\
\text { Rye } \\
\text { Conv. Till }\end{array}$ & $\begin{array}{c}37 . \\
\text { Con SB } \\
\text { Rye } \\
\text { Conv. Till }\end{array}$ \\
\hline Legend & $\begin{array}{l}\mathrm{A} . \\
\mathrm{Aa} \\
\mathrm{Bb} \\
\mathrm{Cc} \leftarrow\end{array}$ & - & $\begin{array}{l}\text { lot Number } \\
\text { rop rotation } \\
\text { Cover crop Tr } \\
\text { illage Treatn }\end{array}$ & $\begin{array}{l}\text { Treatment } \\
\text { eatment } \\
\text { eent }\end{array}$ & $\mathrm{Cl}$ & $\begin{array}{l}\text { p Rotation } \\
\text { B: Corn/Soy } \\
\text { B: Soybean } \\
\text { n Corn: Con } \\
\text { n SB: Contir }\end{array}$ & $\begin{array}{l}\text { bean Rotati } \\
\text { Corn Rotati } \\
\text { inuous Corn } \\
\text { uous Soyber }\end{array}$ & Till & $\begin{array}{l}\text { ve } \\
\text { v. Till: Conv }\end{array}$ & entional Till & \\
\hline
\end{tabular}

Fig. 1. Experimental set up. 
for $72 \mathrm{~h}$. Soil physical properties were calculated as follows: BDY was calculated as a ratio of the oven dry soil weight to the total soil volume. Volumetric water content (VWC) was estimated by subtracting DWS from WWS and dividing by the total soil volume. Gravimetric water content (GWC) was calculated by subtracting DWS from WWS and dividing it by the DWS. Total pore space (TPS) was analysed by subtracting the ratio of BDY to particle density (taken as $2.65 \mathrm{~g} \mathrm{~cm}^{-3}$ ) and subtracting it from 1 (the number one). Volmetric air content (VAC) was calculated by subtracting VWC from TPS. Water-filled (WFPS) and air-filled pore space (AFPS) were calculated as a percent of the ratio of VAC to TPS and as a percent of the ratio of VAC to TPS, respectively. The gas diffusion coefficient (Ds/Do) was estimated by squaring the AFPS, while pore tortuosity factor (Tort) was calculated as the reciprocal of VAC (Nkongolo et al., 2010).

Soil texture was determined by the sieve and pipette method (Smith and Mullins, 1991). After the soil physical properties were calculated, the data was transferred to Minitab version 16.2 for statistical analysis. Analysis was done on the data with respect to moments (the shape of the sample statistical distribution: skewness, kurtosis, mean and standard deviation), and coefficient of variation (CV) at the four sampled depths for each of the plots in all the years of study (results no showed). Because the effects of some of the treatments (cover crop and crop rotation) could only be felt in the second year (2012), analysis of variance differed in 2011 as compared to 2012 and 2013.

\section{RESULTS AND DISCUSSION}

The means for soil texture at the four depths are shown in Table 1. The soil contained more silt than clay and sand in all the depths. The amount of silt slightly decreased in depth $2(10-20 \mathrm{~cm})$ and depth $3(20-40 \mathrm{~cm})$ as compared to depth $1(0-10 \mathrm{~cm})$. Sand, in opposite, was the lowest in depth 1, while clay increased and decreased as we moved deeper into the soil. On the field, sand had the highest variation while silt showed the least variation.

This study began in 2011 and the effect of cover crop and crop rotation treatments on soil physical properties could be felt only in subsequent years. Therefore, the 2011

T a b I e 1. Means for soil texture at four depths in a siltloam soil

\begin{tabular}{cccc}
\hline $\begin{array}{c}\text { Depth of } \\
\text { sampling } \\
(\mathrm{DS})(\mathrm{cm})\end{array}$ & Clay & Silt & Sand \\
\hline $0-10$ & $20.11 \pm 1.02$ & $65.06 \pm 1.47$ & $14.83 \pm 1.97$ \\
$10-20$ & $20.85 \pm 1.02$ & $63.30 \pm 1.50$ & $15.85 \pm 2.03$ \\
$20-40$ & $19.85 \pm 0.91$ & $63.12 \pm 1.30$ & $17.03 \pm 1.79$ \\
$40-60$ & $20.97 \pm 0.87$ & $63.84 \pm 1.61$ & $15.19 \pm 2.04$ \\
\hline
\end{tabular}

analysis focused only on the effects of tillage and depth on soil physical properties (Table 2). The analysis of variance showed significant Tillage $\mathrm{x}$ Depth interactions for AFPS, Ds/Do, Tort, VAC and WFPS. AFPS was the greatest in the $0-10 \mathrm{~cm}$ depth of conventionally tilled plots and the least in the 10-20 cm depth of no-till plots. The difference between the highest AFPS and the least AFPS was about $25 \%$. Ds/ Do was greater in the upper $10 \mathrm{~cm}$ of conventionally tilled plots, but lower in the $40-60 \mathrm{~cm}$ depth of no-till plots. This can be explained by the fact that tillage exposes the soil to sunlight, which increases evaporation of soil moisture therefore increasing the percentage of pore space filled with air. In addition, loose and fluffy soils offer less restriction to gas diffusion compared with a compacted soil. The pore tortuosity factor (Tort) was greater in the $10-20 \mathrm{~cm}$ and the lowest in the $20-40 \mathrm{~cm}$ depth of no-till plots as expected. Volumetric air content had its highest values in the upper $10 \mathrm{~cm}$ of conventionally tilled plots and lowest in the 40-60 cm depth of conventionally tilled plot. Finally, there were more WFPS in the 10-20 cm depth of no-till plots and less in the upper $10 \mathrm{~cm}$ of tilled plots. All the soil physical properties studied were significantly affected by depth of sampling $(\mathrm{p}<0.001)$, as shown in Table 2. However, only GWC and VWC were significantly affected by tillage $(p<0.05)$. GWC and VWC were $8 \%$ and $10 \%$ greater under no-till compared with conventional tillage treatment, respectively.

The effects of tillage, crop rotation, cover crop and depth of sampling on soil physical properties for the second year (2012) are shown in Table 3. Significant cover crop x depth of sampling interactions $(\mathrm{p}<0.05)$ were found for BDY, Ds/ Do, GWC and TPS. In addition, there was a significant crop rotation $\mathrm{x}$ depth of sampling interaction for GWC $(\mathrm{p}<0.05)$. The interaction between cover crop and depth of sampling is presented in Fig. 2 for BDY and TPS, respectively. They suggest that the benefits of the cover crop (rye) roots in decreasing soil bulk density (reducing soil compaction) and increasing total porosity were more prominent in the top $10 \mathrm{~cm}$ of the soil. At deeper depths $(20-60 \mathrm{~cm})$, the influence of rye is no longer felt since BDY and TPS were higher in rye planted plots as compared to no-rye plots. This is understandable, since most rye roots were concentrated in the $0-10 \mathrm{~cm}$ depth. Our results agree with those by Villamil et al. (2006) who reported similar findings. The cover crop x depth of sampling interaction showed that Ds/ Do was $25 \%(0-10 \mathrm{~cm})$ and $14 \%(10-20 \mathrm{~cm})$ greater in plots planted to rye as compared with plots with no cover crop. This same interaction also showed that GWC was $10 \%$ greater in cover crop compared with no cover crop plots in the $10 \mathrm{~cm}$ layer of the soil. Blanco-Canqui et al. (2011) also reported a $4 \%$ increase in soil water content with cover crop. These results suggest an improvement in bio-pores which have been reported to increase water retention and infiltration (Bruce et al., 1992; Joyce et al., 2002; Wilson et al., 1982) and to reduce runoff and soil loss. However, 
T a b l e 2. Effects of tillage and depth of sampling on selected soil physical properties in 2011

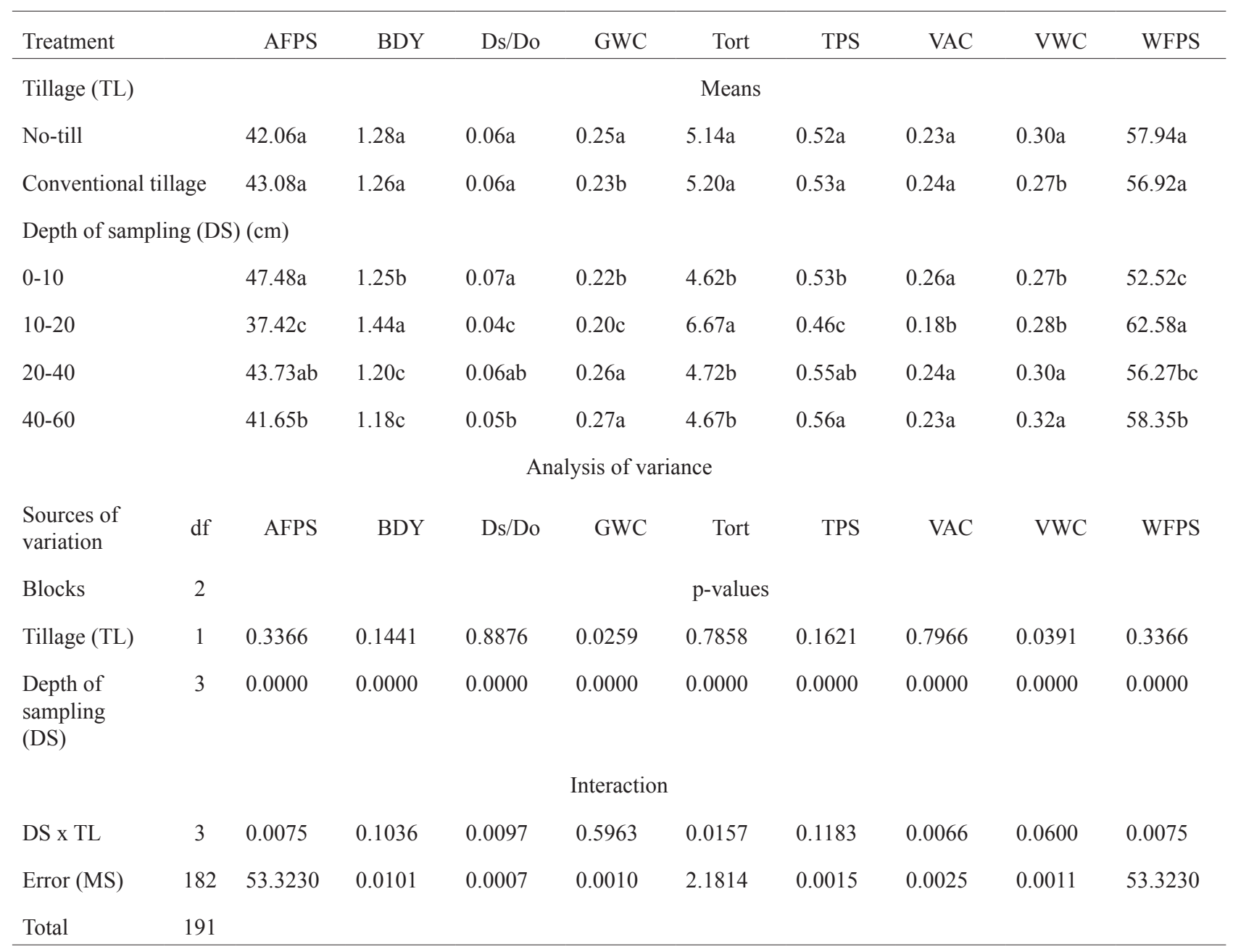

Means followed by different alphabet in the same treatment and depth of sampling are statistically significant at the 0.05 probability level. p-values $<0.05$ are statistically significant. AFPS - air filled pore space (\%); BDY - soil bulk density $\left(\mathrm{g} \mathrm{cm}^{-3}\right)$; Ds/Do - relative gas diffusion coefficient $\left(\mathrm{m}^{2} \mathrm{~s}^{-1} \mathrm{~m}^{-2} \mathrm{~s}\right)$; GWC - gravimetric water content of soil $\left(\mathrm{g} \mathrm{g}^{-1}\right)$; TPS - total pore spaces $\left(\mathrm{cm}^{3} \mathrm{~cm}^{-3}\right)$; Tort: pore tortuosity factor $\left(\mathrm{m} \mathrm{m}^{-1}\right)$; VAC - volumetric air content $\left(\mathrm{cm}^{3} \mathrm{~cm}^{-3}\right)$; VWC - volumetric water content $\left(\mathrm{cm}^{3} \mathrm{~cm}^{-3}\right)$; WFPS - water filled pore space $(\%)$.

in contrast, Ewing et al. (1991) suggested that cover crop lowered soil moisture and reduced the productivity of subsequent cash crops. Finally, the interaction between crop rotation and depth of sampling suggested that GWC was $42 \%$ greater in corn/soybean rotation compared with continuous soybean treatment where GWC was the lowest. This is understandable, as after harvest corn residues were left on the soil and therefore helped to reduce evapotranspiration. Fewer residues were left in a soybean monoculture. The cover crop alone also significantly affected BDY and TPS $(p<0.05)$. Although not significant, we did notice an increase in AFPS, Ds/Do and VAC in plots with cover crop (Rye), confirming a potential increase of bio-pores, which improved infiltration as suggested by Joyce et al. (2002).

The effects of tillage, cover crop, crop rotation, and depth of sampling on soil physical properties after the threeyear study (2013) are shown in Table 4. In contrast to the previous assessments, this analysis focused only on the first two depths $(0-10$ and 10-20 cm) where the effect of cover crop would be more felt, given its short rooting system. In comparison to the first two years of this study, soil physical properties responded differently to tillage, crop rotation, cover crop, and depth of sampling. In fact, the analysis of variance showed that none of the interactions reported in 2012 were present in 2013, suggesting that the interactions between various soil and crop management practices are complex in nature and their effects on soil physical properties may not be easily predictable.

Bulk density was significantly affected by cover crop $\mathrm{x}$ crop rotation and cover crop $\mathrm{x}$ tillage interactions. These interactions are presented in Figs 3 and 4. Figure 3 suggests that the addition of a cover crop to monocultures of soybean and corn increased soil bulk density in comparison to no cover crop plots. However, in rotation plots the addition 
T a b l e 3. Effects of tillage, crop rotation, cover crop and depth of sampling on selected soil physical properties in 2012

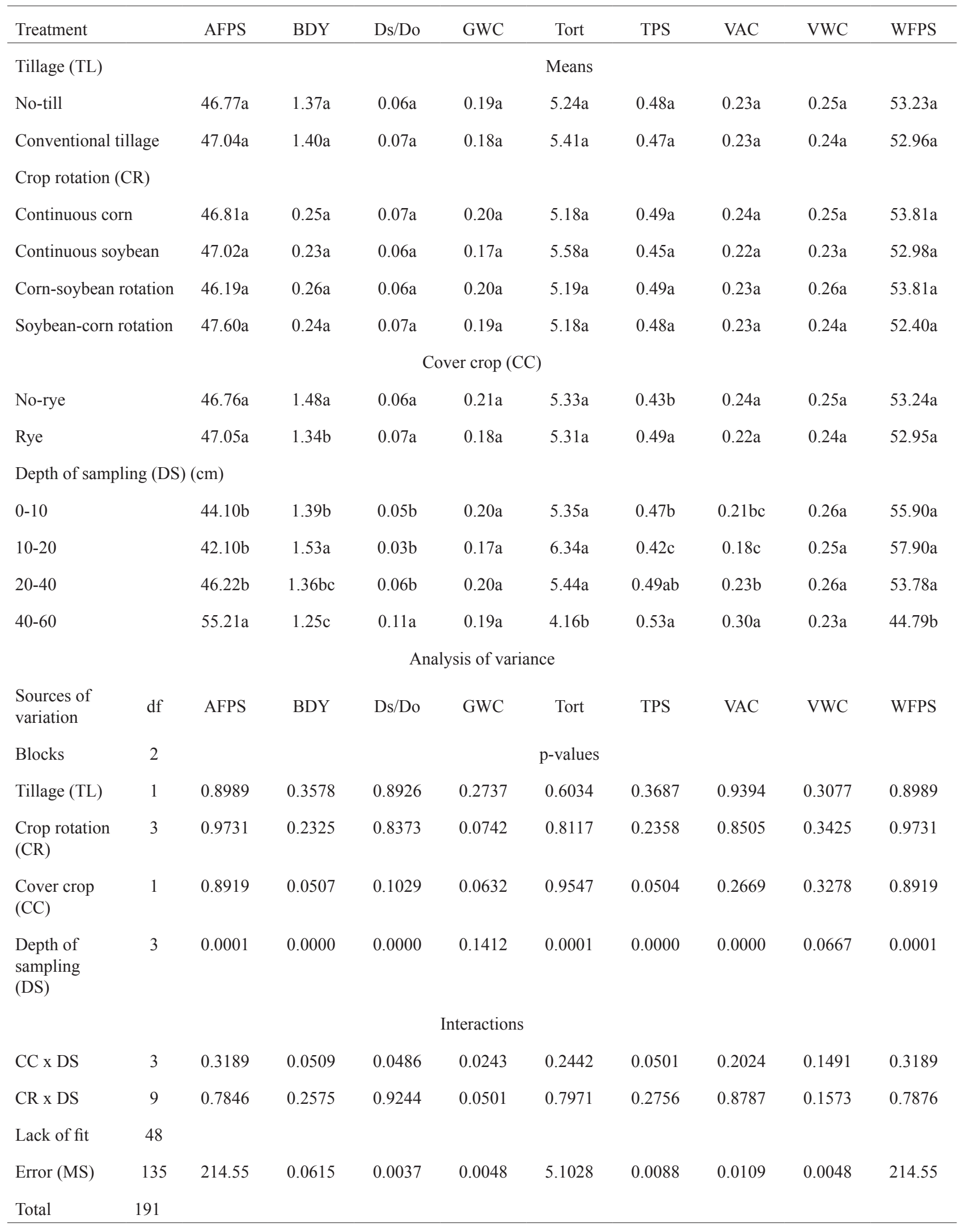

Explanations as in Table 2. 

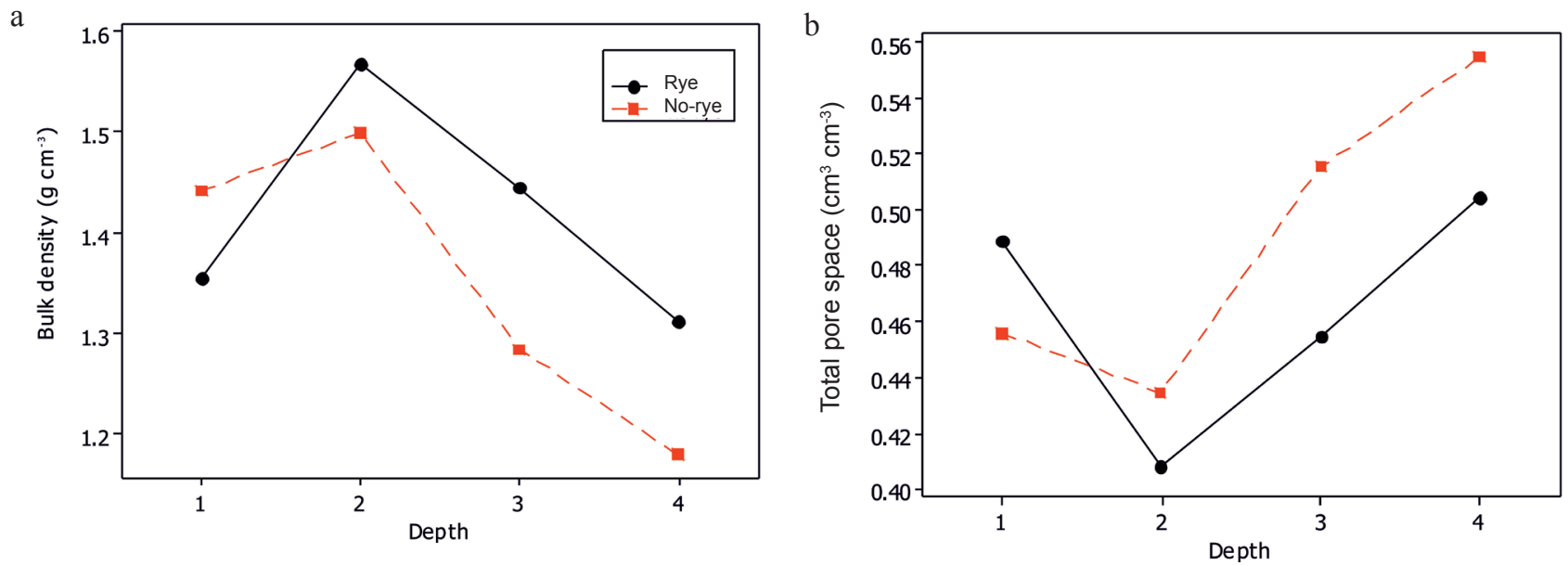

Fig. 2. Effect of cover crop $\mathrm{x}$ depth of sampling interaction on: $\mathrm{a}$ - bulk density, $\mathrm{b}$ - total pore spaces in 2012; $1-0$-10, 2 - 10-20, $3-20-40,4-40-60 \mathrm{~cm}$.

of a cover crop reduced soil bulk density. The exact reason for this is still unclear but we can speculate that the various rooting systems of the crops in the rotation cycle coupled with the rye roots are responsible for reducing BDY.

The tillage $\mathrm{x}$ cover crop interaction (Fig. 4) shows that under no-till management, planting rye caused a 3\% reduction in BDY compared with when rye was not planted. Blanco-Canqui et al. (2011) reported similar findings. However, in tilled plots, BDY was increased when rye was added. In fact, annual tillage causes soils to settle and later increases BDY, and planting a cover crop may not be able to immediately alleviate this problem, especially if tillage is practiced continuously, year after year.

Soil total pore space (TPS) was significantly affected by cover crop $\mathrm{x}$ crop rotation and cover crop $\mathrm{x}$ tillage interactions. A similar but opposite trend as for BDY was observed for TPS (Fig. 5). TPS was the lowest in corn and soybean monocultures although rye was added. However, TPS increased in rotation plots with the addition of rye. This suggests that bio-pores contributed by microbial movement in undisturbed soils (Reeleder et al., 2006) and cover crop roots may have improved soil porosity. The cover crop $\mathrm{x}$ tillage interaction showed that TPS was generally greater with no-till management with rye (Fig. 6).

Soil gravimetric water content (GWC) was significantly affected by cover crop $\mathrm{x}$ crop rotation $\mathrm{x}$ depth of sampling and cover crop $\mathrm{x}$ depth of sampling $\mathrm{x}$ tillage interactions (Table 4). The first interaction (figure not showed) suggested that in the top $10 \mathrm{~cm}$ of the soil, planting rye in continuous corn and soybean-corn rotations was beneficial for soil moisture compared with no rye. In the soybean/ corn rotation particularly, the moisture content when rye was previously planted was $16 \%$ greater compared with no previous rye. The cover crop $\mathrm{x}$ depth of sampling $\mathrm{x}$ tillage interaction for GWC showed that, in the first depth, soil moisture was generally greater under no-till management. However, under conventional tillage management, soil moisture was $6 \%$ greater when rye was planted. The opposite was observed in the second depth. At this depth, the greatest moisture content was noticed under no-till and cover crop managements.

Finally, AFPS, Ds/Do, GWC,VAC, VWC and WFPS were all significantly affected by depth of sampling (Table 4). VAC was $4 \%$ greater in the second depth compared with the first depth, and it corresponded with what was found for AFPS and Ds/Do. VWC and WFPS were both greater in the first depth of sampling. VWC and WFPS were 14\% and $16 \%$ greater in the first depth compared with the second depth, respectively.

\section{CONCLUSIONS}

1. In the first year of this study, gravimetric and volumetric were 8 and $10 \%$ greater under no-till treatment compared with conventional tillage treatment, respectively.

2. In the second year, we noted that planting rye reduced bulk density by $9 \%$ and increased total pore space by $12 \%$.

3. In the third year of the study, tillage $x$ cover crop interaction showed that under no-till management, planting rye caused a $3 \%$ reduction in bulk density compared with when rye was not planted, suggesting that the improvement of bulk density by cover crop roots is enhanced with no-till management since there was no main effect of cover crop on bulk density.

4. The cover crop $\mathrm{x}$ crop rotation interaction suggested that the effect of cover crop in improving soil physical properties (bulk density, total pore space) was more apparent in rotation than in monoculture (continuous cropping) plots.

5. The interactions between various agricultural management treatments are complex in nature and their effects on soil physical properties may not be easily predictable. 
T a b l e 4. Effects of tillage, crop rotation, cover crop and depth of sampling on selected soil physical properties in 2013

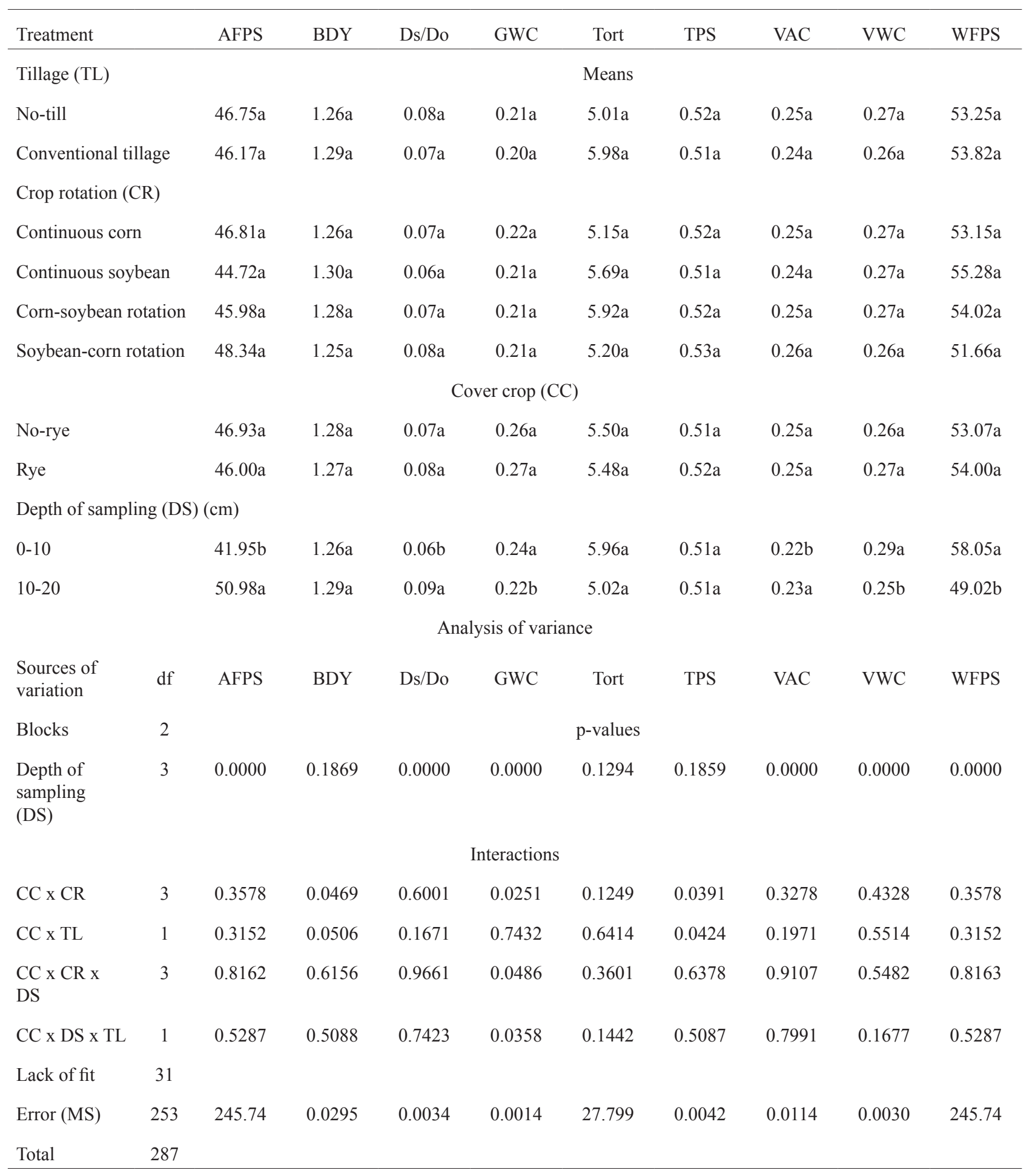

Explanations as in Table 2. 


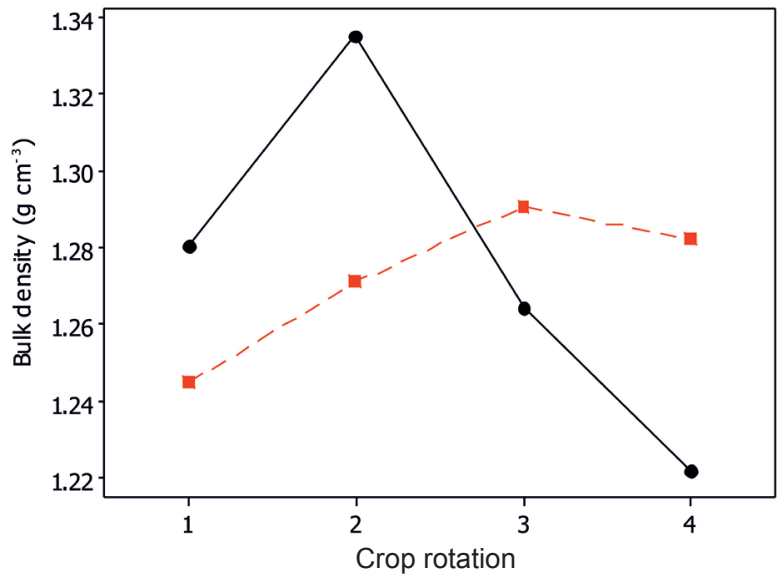

Fig. 3. Effect of cover crop $x$ crop rotation interaction on soil bulk density in 2013. 1 - continuous corn, 2 - continuous soybean, 3 - corn/soybean rotation, 4 - soybean/corn rotation. Legend as in Fig. 2.

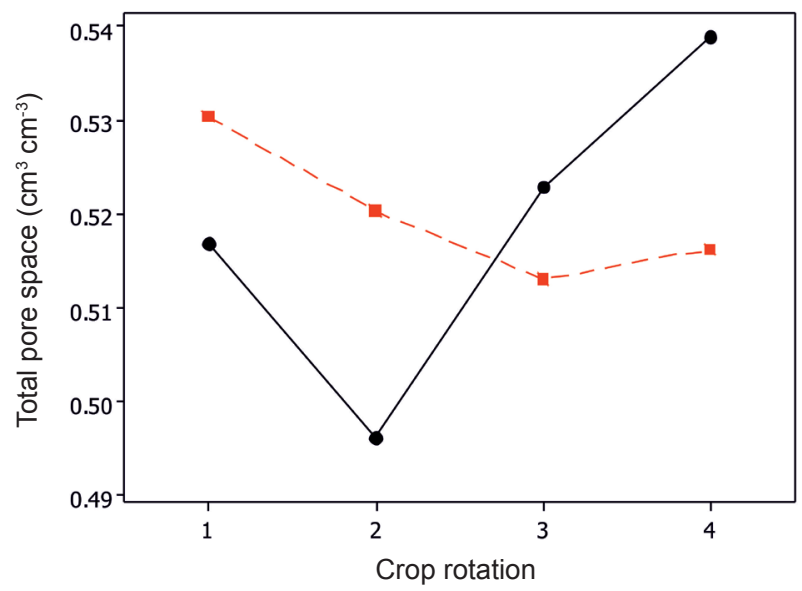

Fig. 5. Effect of cover crop $x$ crop rotation interaction on total pore space in 2013. Explanations as in Fig. 3. Legend as in Fig. 2.

\section{REFERENCES}

Anken T., Weisskopf P., Zihlmann U., Forrer H., Jansa J., and Perhacova K., 2004. Long-term tillage system effects under moist cool conditions in Switzerland. Soil Till. Res., 78, 171-183.

Arshad M.A., Franzluebbers A.J., and Azooz R.H., 1999. Components of surface soil structure under conventional and notillage in northwestern Canada. Soil Till. Res., 53, 41-47.

Blanco-Canqui H., Mikha M.M., Presley D.R., and Claassen, M.M., 2011. Addition of cover crops enhances no-till potential for improving soil physical properties. Soil Sci. Soc. Am. J., 75, 1471-1482.

Bruce R.R., Langdale G.W., West L.T., and Miller W.P., 1992. Soil surface modification by biomass inputs affecting rainfall infiltration. Soil Sci. Soc. Am., 56, 1614-1620.

Buschiazzo D.E., Panigatti J.L., and Unger P.W., 1998. Tillage effects on soil properties and crop production in the subhumid and semiarid Argentinean Pampas. Soil Till. Res., 49, 105-116.

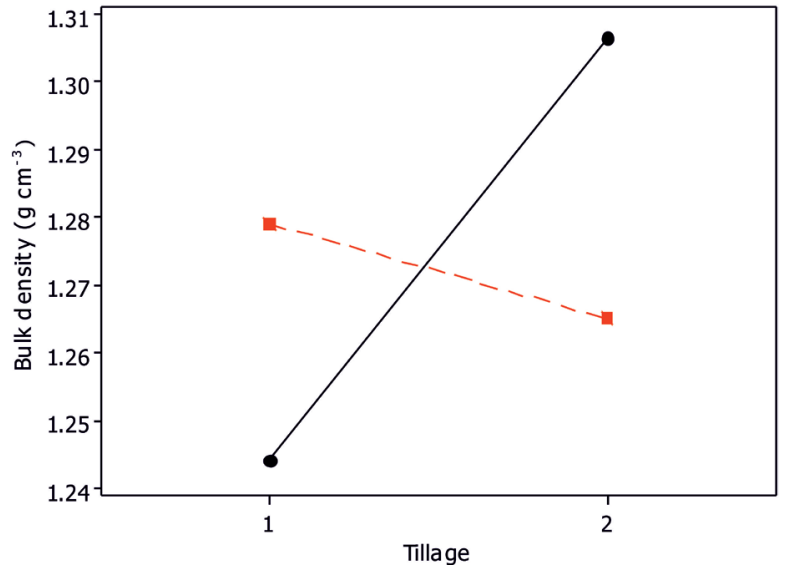

Fig. 4. Effect of tillage $x$ cover crop interaction on soil bulk density in 2013. 1 - no till, 2 - conventional tillage. Legend as in Fig. 2.

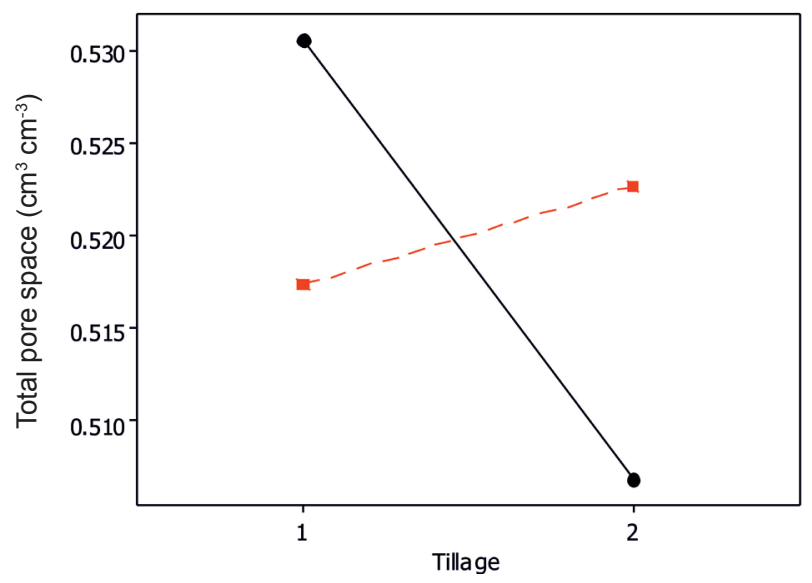

Fig. 6. Effect of tillage $x$ cover crop interaction on total pore space in 2013. Explanations as in Fig. 4. Legend as in Fig. 2.

Ewing R.P., Wagger M.G., and Denton H.P., 1991. Tillage and cover crop management effects on soil ater and corn yield. Soil Sci. Soc. Am. J., 55, 1081-1085.

Gómez J.A., Giráldez J.V., Pastor M., and Fereres E., 1999. Effects of tillage method on soil physical properties, infiltration and yield in an olive orchard. Soil Till. Res., 52, 167-175.

Grant C.A. and Lafond G.P., 1993. The effects of tillage systems and crop sequences on soil bulk density and penetration resistance on a clay soil in southern Saskatchewan. Can. J. Soil Sci., 73, 223-232.

Hill R.L., 1990. Long-term conventional and no-tillage effects on selected soil physical properties. Soil Sci. Soc. Am. J., 54, 161-166.

Hussain I., Olson K.R., and Siemens L.C., 1998. Long-term tillage effects on physical properties of eroded soil. Soil Sci., 163, 970-981.

Joyce B.A., Wallender W.W., Mitchell J.P., Huyck L.M., Temple S.R., Brostrom P.N., and Hsiao T.C., 2002. 
Infiltration and soil water storage under winter cover cropping in California's Sacramento Valley. Trans. ASAE, 45, 315-326.

Logsdon S.D., Kaspar T.C., and Cambardella C.A., 1999. Depth-incremental soil properties under no-till or chisel management. Soil Sci. Soc. Am. J., 63, 197-200.

Mahboubi A.A., Lal R., and Faussey, N.R., 1993. Twenty-eight years of tillage effects on two soils in Ohio. Soil Sci. Soc. Am. J., 57, 506-512.

Nkongolo N.V., Hatano R., and Kakembo V., 2010. Diffusivity models and greenhouse gases fluxes from a forest, pasture, grassland and corn field in Northern Hokkaido, Japan. Pedosphere, 20, 747-760.

Osunbitan J.A., Oyedele D.J., and Adekalu K.O., 2005. Tillage effects on bulk density, hydraulic conductivity and strength of a loamy sand soil in southwestern Nigeria. Soil Till. Res., $82,57-64$.

Özgöz E., Akbş F., Çetin M., Erşahin S., and Günal H., 2007. Spatial variability of soil physical properties as affected by different tillage systems. N. Z. J. Crop Hortic. Sci., 35, 1-13.

Radcliffe D.E., Clark R.L., Tollner E.W., Hargrove W.L., and Golabi M.H., 1988. Effect of tillage practices on infiltration and soil strength of a typic hapludult soil after ten years. Soil Sci. Soc. Am. J., 52, 798-804.

Raper R.L., Reeves D.W., Burmester C.H., and Schwab E.B., 2000. Tillage depth, tillage timing, and cover crop effects on cotton yield, soil strength, and tillage energy requirements. Appl. Eng. Agric., 16, 379-385.

Reeleder R.D., Miller J.J., Ball Coelho B.R., and Roy R.C., 2006. Impacts of tillage, cover crop, and nitrogen on populations of earthworms, microarthropods, and soil fungi in a cultivated fragile soil. Appl. Soil Ecol., 33, 243-257.
Rhoton F.E., Bruce R.R., Buehring N.W., Elkins G.B., Langdale C.W., and Tyler D.D., 1993. Chemical and physical characteristics of four soil types under conventional and no-tillage systems. Soil Till. Res., 28, 51-61.

Sharratt B., Zhang M., and Sparrow S., 2006. Twenty years of tillage research in subarctic Alaska: I. Impact on soil strength, aggregation, roughness, and residue cover. Soil Till. Res., 91, 75-81.

Smith K.A. and Mullins C.E., 1991. Soil analysis: physical methods. Marcel Dekker Press, New York, USA.

Strudley M.W., Green T.R., and Ascough II, J.C., 2008. Tillage effects on soil hydraulic properties in space and time: State of the science. Soil Till. Res., 99, 4-48.

Taboada M.A., Micucci F.G., Cosentino D.J., and Lavado R.S., 1998. Comparison of compaction induced by conventional and zero tillage in two soils of the Rolling Pampa of Argentina. Soil Till. Res., 49, 57-63.

Tsegaye T. and Hill R.L., 1998. Intensive tillage effects on spatial variability of soil physical properties. Soil Sci., 163, 143-154.

Villamil M.B., Bollero G.A., Darmody R.G., Simmons F.W., and Bullock, D.G., 2006. No-till corn/soybean systems including winter cover crops. Soil Sci. Soc. Am. J., 70, 1936-1944.

Wander M.M., and Bollero G.A., 1999. Soil quality assessment of tillage impacts in Illinois. Soil Sci. Soc. Am. J., 63, 961-971.

Wilson G.F., Lal R., and Okigbo B.N., 1982. Effects of cover crops on soil structure and on yield of subsequent arable crops grown under strip tillage on an eroded Alfisol. Soil Till. Res., 2, 233-250. 